\title{
Study of Beijiang catchment flash-flood forecasting model
}

\author{
YANGBO CHEN, JI LI, SHAOKUN HUANG \& YI DONG \\ Laboratory of Water Disaster Management and Hydroinformatics, Sun Yat-sen University, 135 Xingangxi Road, \\ Guangzhou 510275, China \\ eescyb@mail.sysu.edu.cn
}

\begin{abstract}
Beijiang catchment is a small catchment in southern China locating in the centre of the storm areas of the Pearl River Basin. Flash flooding in Beijiang catchment is a frequently observed disaster that caused direct damages to human beings and their properties. Flood forecasting is the most effective method for mitigating flash floods, the goal of this paper is to develop the flash flood forecasting model for Beijiang catchment. The catchment property data, including DEM, land cover types and soil types, which will be used for model construction and parameter determination, are downloaded from the website freely. Based on the Liuxihe Model, a physically based distributed hydrological model, a model for flash flood forecasting of Beijiang catchment is set up. The model derives the model parameters from the terrain properties, and further optimized with the observed flooding process, which improves the model performance. The model is validated with a few observed floods occurred in recent years, and the results show that the model is reliable and is promising for flash flood forecasting.
\end{abstract}

Key words: flood forecasting; flash flood; Liuxihe model; areal precipitation; parameter optimization

\section{INTRODUCTION}

Beijiang catchment is a small catchment in southern China locating in the center of the storm areas of the Pearl River Basin. Flash flooding in Beijiang catchment is a frequently observed disaster that caused direct damages to human beings and their properties. As most of the catchment area is in the mountainous area, engineering measurement for flood mitigation could not be easily built, so no-engineering measurement is the main choose for mitigating flash floods of Beijiang catchment.

Flood forecasting model is the main tool for flood forecasting. Early flood forecasting models are so called lumped conceptual hydrological models, such as the Stanford model (Crawford et al., 1966), the Sacramento model (Burnash, 1995), the Tank model (Sugawara, 1995), the Xinanjiang model (Zhao, 1977), and the ARNO model (Todini, 1996). Lumped models calibrate the model parameters using long series of observed hydrologic and meteorological data, so long series observed hydrologic and meteorological data are needed to implement the lumped model, and this is difficult for Beijiang catchment. Physically based distributed hydrological models are the latest development of catchment hydrological models, which derive model parameters from the terrain properties, and use only a few observed hydrological processes to adjust the model parameters, thus having the potential to be used in Beijiang catchment for flash flood forecasting.

The first physically-based distributed hydrological model, the Systeme Hydrologique European (SHE) model was published in 1986 (Abbott et al., 1986a,b), after that, more models have been proposed, such as WATFLOOD (Kouwen et al., 1988), VIC (Liang et al., 1994), CASC2D (Julien and Saghafian, 1995), WetSpa (Wang et al., 1996), Vflo (Vieux et al., 2002), Liuxihe Model (Chen et al., 2008, 2011), among others. Physically-based distributed hydrological model divides the whole catchment into a number of grid cells, identifies different parameter values for different cells based on their physical properties, and assigns specific precipitation to each grid cell, so this kind of model has the potential to better represent the catchment hydrological processes, and is regarded as the next generation hydrological model.

This paper, based on the Liuxihe Model, sets up the flash flood forecasting model for Beijiang catchment. The catchment property data, including DEM, land cover types and soil types are downloaded from the website freely. The model derives the model parameters from the terrain properties, and further optimized with one observed flooding process, which improved the model performance largely. The model is validated with a few observed floods occurred in recent years, and the results show that the model is reliable and is promising for flash flood forecasting of Beijiang catchment. 


\section{DATA AND METHOD}

\section{Beijiang catchment}

Beijiang catchment locates in Ronshui county of Guangxi Province with a drainage area of 1790 $\mathrm{km}^{2}$ and a length of $130 \mathrm{~km}$. The catchment has a dense channel system, and is surrounded by high mountains with peak elevation over $1000 \mathrm{~m}$, including the Daimiaoshan Mountain chain in the northeast with a peak elevation of $2018 \mathrm{~m}$, the Big Jiuwanshan Mountain chain in the west with a peak elevation of $1978 \mathrm{~m}$. Figure 1 is a sketch map of the catchment.

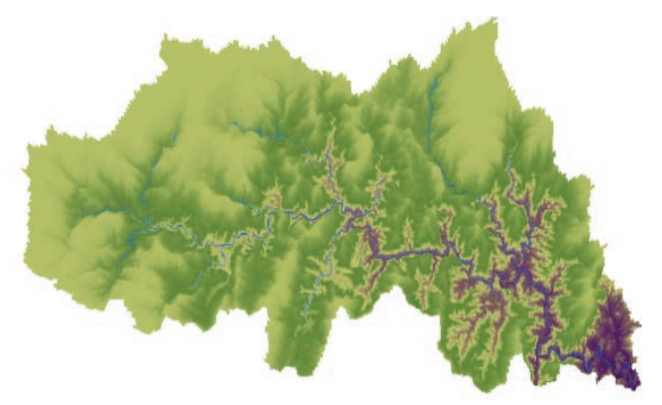

(a) Three-dimensional topography

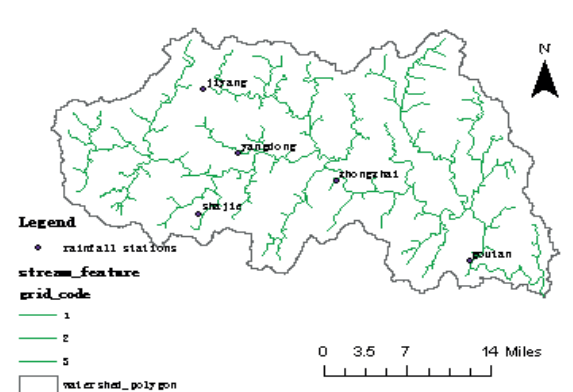

(b) River system and rainfall stations

Fig. 1 sketch map of Beijiang catchment.

Beijiang catchment is in the centre of the storm area of Guangxi Province, its event precipitation is high. The observed maximum 12 hour accumulated precipitation is $644.19 \mathrm{~mm}$, maximum 24 hour accumulated precipitation is $779.11 \mathrm{~mm}$, and the maximum 3day accumulated precipitation is $1335.15 \mathrm{~mm}$. The floods are caused by storms, and are the typical flash flood with rapid discharge and water level fluctuation.

\section{Catchment property data}

Catchment property data are needed for model set up and parameter determination, including the DEM, land-use types and soil types, these data are downloaded from the website. The DEM is downloaded from the Shuttle Radar Topography Mission database website at http://srtm.csi.cgiar.org, the land-use type is downloaded from http://landcover.usgs.gov, and the soil type is downloaded from http://www.isric.org. The DEM is at the spatial resolution of $90 \mathrm{~m} \times$ $90 \mathrm{~m}$, but the other two data are at the $1000 \mathrm{~m} \times 1000 \mathrm{~m}$ resolution, and are rescaled to the spatial resolution of $90 \mathrm{~m} \times 90 \mathrm{~m}$. Figure 2 shows the catchment property data.

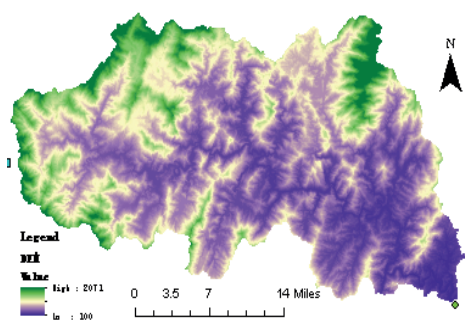

(a) DEM

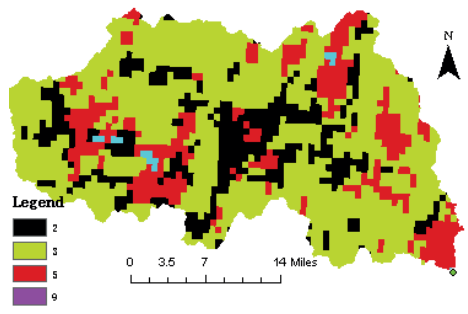

(b) Land use type

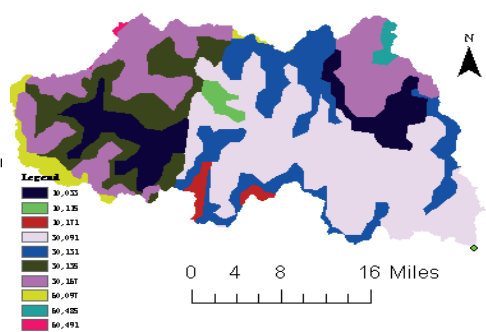

(c) Soil type

Fig. 2 Catchment property data.

From the results it has been found, the highest elevation of the catchment is $2071 \mathrm{~m}$, the average elevation is $469 \mathrm{~m}$. There are four land-use types, including evergreen needle leaved forest, evergreen broad-leaf forest, shrub and slope grassland, accounting for $27.6 \%, 36.5 \%, 25.5 \%$, and $10.4 \%$ of the total basin area respectively. There are 10 soil types, including Artificial accumulated soil, Haplicluvisols, Haplic and high activitive acrisol, Haplic and weak active acrisol, Humicacrisol, Ferric weak active acrisol, Eutricgleysols, Dystricregosols, Eutricregosols and 
Black limestone soil, accounting for 4.8\%, 56.5\%, 1.7\%, 3.4\%, 6.5\%, 4.5\%, 0.7\%, 5.6\%, 9.8\% and $6.5 \%$ of the total basin area respectively.

\section{Observed hydrological data}

In this study, hydrological data including precipitation and discharge at the catchment outlet of seven flood events in the past has been collected. There are five raingauges installed in this catchment, their locations are shown in Fig. 1. For the raingauge observed precipitation, it is interpolated to the grid cells with Thiesson Polygon method.

\section{Liuxihe Model}

Liuxihe Model (Chen et al., 2008, 2011) is a physically-based distributed hydrological model mainly for catchment flood forecasting. The model is divided into several sub-models, including the Basin Digitization Model (BDM), the Data Preparation Model (DPM), the Evapotranspiration Model (EM), the Runoff Production Model (RPM), the Runoff Routing Model (RRM) and the Parameter Deriving Model (PDM). The BDM divides the studied basin into a number of cells horizontally which are further divided into three layers vertically, while DPM prepares data for every cell to derive model parameters and run the model. EM calculates the evapotranspiration occurring in the cells, the RPM determines the runoff produced in every cell, the RRM routes the runoff produced in every cell to the basin outlet, and the PDM derives model parameters.

In Liuxihe model, the studied area is divided into a number of cells horizontally by using a DEM, the cells are called a unit-basin, and are treated as a uniform basin in which elevation, vegetation type, soil characteristics, rainfall, and thus model parameters are considered to take the same value. The unit-basin is then divided into three layers vertically, including the canopy layer, the soil layer and the underground layer. The boundary of the canopy layer is from the terrain surface to the top of the vegetation. The evapotranspiration takes place in this layer, and the Evapotranspiration Model is used to determine the evapotranspiration at the unit-basin scale. In the soil layer, soil water is filled by the precipitation and depleted via evapotranspiration. The underground layer is beneath the soil layer with a steady underground flow that is recharged by percolation. All cells are categorized into three types: hill slope cell, river cell and reservoir cell.

There are five different runoff routings in Liuxihe model, including hill slope routing, river channel routing, interflow routing, reservoir routing and underground flow routing. Hill slope routing is used to route the surface runoff produced in one hill slope cell to its neighbouring cell, and the kinematical wave approximation is employed to make this runoff routing. For the river channel routing, the shape of the channel cross-section is assumed to be trapezoid, which makes it estimated by satellite images, and the one dimensional diffusive wave approximation is employed to make this routing.

The parameters in Liuxihe model are summarized as evapotranspiration parameters, runoff parameters and routing parameters, and are inclusively related to one terrain property. The parameters are divided into adjustable parameters and unadjustable parameters. The former is derived from the terrain property, and will remain unadjusted. For the latter, it will be adjusted after its preliminary value is presented based on the terrain properties. The adjustable parameters are further divided into highly sensitive parameters, sensitive parameters and insensitive parameters. Adjustable parameters could either be adjusted manually or automatically.

\section{MODEL SET UP AND PARAMETER DETERMINATION}

\section{Model set up}

The catchment is divided into cells with the collected DEM, and is categorized as three types, including hill slope cell, river channel cell and reservoir cell. As there is no significant reservoir in the catchment, so there is no reservoir cell. The river channel system is divided into three orders, 126 virtual sections have been set, and their cross-section sizes have been estimated by referencing to Google Earth images. The model structure is shown in Fig. 3. 


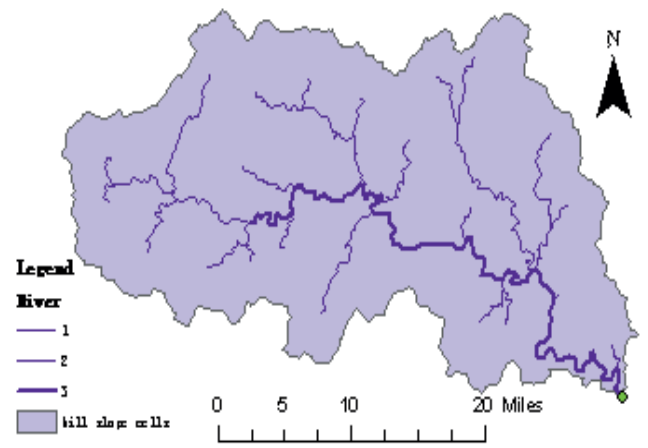

(a) Hill slope cells

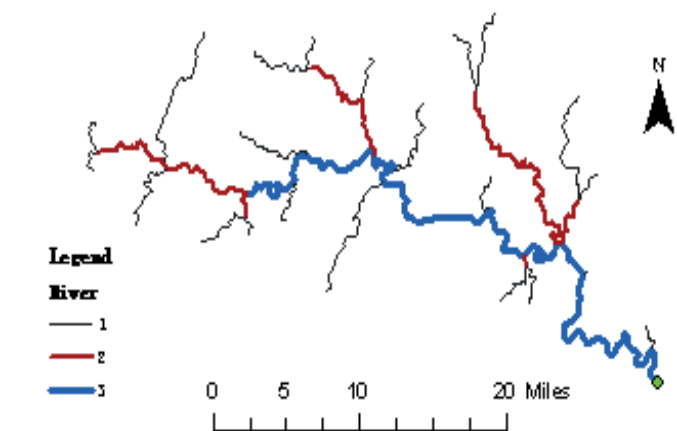

(b) River channel cells

Fig. 3 Model structure of the Beijiang catchment.

\section{Determination of the preliminary values of the model parameters}

The preliminary values of the model parameters are derived from the cell properties, see Tables 1 and 2 .

Table 1 Preliminary values of land cover related parameters.

\begin{tabular}{lll}
\hline Land-use type & $\begin{array}{l}\text { The roughness factor preliminary } \\
\text { values of hill slope cells }\end{array}$ & $\begin{array}{l}\text { The roughness factor preliminary } \\
\text { values of evaporation coefficient }\end{array}$ \\
\hline Evergreen needle leaved forest & 2 & 0.7 \\
Evergreen broad-leaf forest & 3 & 0.7 \\
Shrub & 5 & 0.7 \\
Slope grassland & 9 & 0.7 \\
\hline
\end{tabular}

Table 2 Preliminary values of soil related parameters.

\begin{tabular}{lllllll}
\hline Soil type & $\begin{array}{l}\text { Soil layer } \\
\text { thickness } \\
(\mathrm{mm})\end{array}$ & $\begin{array}{l}\text { \% sat. } \\
\text { water } \\
\text { content }\end{array}$ & $\begin{array}{l}\text { Field } \\
\text { capacity } \\
(\%)\end{array}$ & $\begin{array}{l}\text { Saturated } \\
\text { hydraulic } \\
\text { conductivity }(\mathrm{h} / \mathrm{d})\end{array}$ & $\begin{array}{l}\text { Soil } \\
\text { coeff. } \\
b\end{array}$ & $\begin{array}{l}\text { \% wilting } \\
\text { percentage }\end{array}$ \\
\hline Artificial accumulated soil & 700 & 0.515 & 0.362 & 3 & 2.5 & 0.2 \\
Haplicluvisols & 1000 & 0.517 & 0.369 & 3 & 2.5 & 0.206 \\
$\begin{array}{l}\text { Haplic and high active } \\
\text { acrisol }\end{array}$ & 250 & 0.450 & 0.234 & 8 & 2.5 & 0.119 \\
Haplic and weak active & 1000 & 0.459 & 0.250 & 8 & 2.5 & 0.121 \\
acrisol & 820 & 0.385 & 0.164 & 34 & 2.5 & 0.076 \\
Humicacrisol & 700 & 0.419 & 0.193 & 15 & 2.5 & 0.1 \\
Ferric weak active acrisol & 150 & 0.43 & 0.203 & 10 & 2.5 & 0.113 \\
Eutricgleysols & 430 & 0.495 & 0.312 & 4 & 2.5 & 0.156 \\
Dystricregosols & 1000 & 0.550 & 0.501 & 2 & 2.5 & 0.357 \\
Eutricregosols & 1000 & 0.500 & 0.324 & 3 & 2.5 & 0.172 \\
Black limestone soil & 1000 & & & &
\end{tabular}

\section{RESULTS}

\section{Flood simulation with preliminary parameters}

The seven flood events have been simulated with the model setting up with the preliminary parameter as listed in Table 1 and Table 2, and the six simulated hydrological processes have been shown in Fig. 4.

From the results shown in Fig. 4, it could be found that the overall simulation result is not so satisfactory, and the model parameter adjustment or optimization may be needed.

\section{Parameter optimization}

The model parameters are optimized by using the Particle Swam Optimization algorithm (PSO) with flood event No.3, and the parameter adjusting coefficient is listed in Table 3. The parameter 
optimization ends after 1200 searches, and the simulation result is improved largely and fits the observed hydrograph well.

Table 3 Results of the parameter adjusting coefficient.

\begin{tabular}{llllll}
\hline $\begin{array}{l}\text { Sat. hydraulic } \\
\text { conductivity } K S\end{array}$ & $\begin{array}{l}\text { Slope } \\
\text { roughness } n\end{array}$ & $\begin{array}{l}\text { Channel } \\
\text { roughness Man }\end{array}$ & $\begin{array}{l}\text { Soil layer } \\
\text { thickness } Z s\end{array}$ & Soil coefficient $b$ & $\begin{array}{l}\text { Bottom slope } \\
B S\end{array}$ \\
\hline 1.35 & 1.14 & 1.50 & 1.30 & 1.44 & 0.50 \\
\hline Bottom width $B w$ & $\begin{array}{l}\text { Saturated soil } \\
\text { moisture } \\
\text { content } C \text { sat }\end{array}$ & $\begin{array}{l}\text { Field Capacity } \\
C f c\end{array}$ & $\begin{array}{l}\text { Evaporation } \\
\text { coefficient } v\end{array}$ & $\begin{array}{l}\text { Wilting } \\
\text { percentage } C w l\end{array}$ & $\begin{array}{l}\text { Grade of side } \\
\text { slope } S s\end{array}$ \\
\hline 1.49 & 0.92 & 0.67 & 0.50 & 1.25 & 0.70 \\
\hline
\end{tabular}

\section{Flood simulation with optimized parameters}

The other six flood events have been simulated with the optimized parameters. Table 4 lists six evaluation index of the six simulated flood events with both the preliminary parameters and the optimized parameters. Figure 4 shows the simulated hydrological processes of the six flood events.

From these results, it could be found that with parameter optimization, the model performances have been improved largely, and the model simulates the flood events reasonable well, so could be used for real-time flash flood forecasting.

Table 4 Flood simulation results with optimized parameters.

\begin{tabular}{|c|c|c|c|c|c|c|c|}
\hline $\begin{array}{l}\text { Flood } \\
\text { events }\end{array}$ & $\begin{array}{l}\text { Parameters (prelim / } \\
\text { optimized) }\end{array}$ & $\begin{array}{l}\text { Certainty } \\
\text { coefficient }\end{array}$ & $\begin{array}{l}\text { Correlation } \\
\text { coefficient }\end{array}$ & $\begin{array}{l}\text { Process } \\
\text { relative } \\
\text { error }\end{array}$ & $\begin{array}{l}\text { Flood } \\
\text { peak error }\end{array}$ & $\begin{array}{l}\text { Water } \\
\text { balance } \\
\text { coeff. }\end{array}$ & $\begin{array}{l}\text { Peak time } \\
\text { error } \\
\text { (h) }\end{array}$ \\
\hline \multirow{2}{*}{1965080608} & preliminary & 0.500 & 0.566 & 0.374 & 0.022 & 0.599 & 3 \\
\hline & optimized & 0.754 & 0.893 & 0.260 & 0.137 & 0.956 & 3 \\
\hline \multirow{2}{*}{1966062020} & preliminary & 0.525 & 0.798 & 0.257 & 0.110 & 0.961 & 0 \\
\hline & optimized & 0.731 & 0.870 & 0.172 & 0.009 & 1.048 & -1 \\
\hline \multirow{2}{*}{1970071214} & preliminary & 0.531 & 0.926 & 0.233 & 0.330 & 0.795 & 3 \\
\hline & optimized & 0.899 & 0.934 & 0.179 & 0.015 & 0.856 & 3 \\
\hline \multirow{2}{*}{1977060804} & preliminary & 0.622 & 0.822 & 0.343 & 0.004 & 0.794 & -2 \\
\hline & optimized & 0.808 & 0.916 & 0.240 & 0.007 & 0.876 & -2 \\
\hline \multirow{2}{*}{1982051109} & preliminary & 0.600 & 0.418 & 0.398 & 0.079 & 0.644 & -1 \\
\hline & optimized & 0.968 & 0.889 & 0.242 & 0.088 & 1.049 & -1 \\
\hline \multirow{2}{*}{1982061406} & preliminary & 0.498 & 0.768 & 0.326 & 0.099 & 0.849 & -1 \\
\hline & optimized & 0.898 & 0.952 & 0.338 & 0.013 & 0.961 & -1 \\
\hline \multirow{2}{*}{ Mean value } & preliminary & 0.546 & 0.716 & 0.322 & 0.107 & 0.774 & 1.67 \\
\hline & optimized & 0.843 & 0.909 & 0.239 & 0.045 & 0.958 & 1.83 \\
\hline
\end{tabular}

\section{CONCLUSIONS}

This paper sets up a flash flood forecasting model for Beijiang catchment by using Liuxihe Model, and the catchment property data for setting up the model, including DEM, land cover types and soil types are downloaded from the website freely. The model derives the preliminary model parameters from the terrain properties, and further optimized with one observed flooding process, which improved the model performance largely. The model is validated with a few observed floods occurred in recent years, and the results show the model is reliable and is promising for flash flood forecasting of Beijiang catchment. This also implies that the distributed hydrological model is useful, and could be employed for flash flood forecasting. As the data for model setting up could be downloaded freely for the global areas, so the model could be used inexpensively worldwide. 


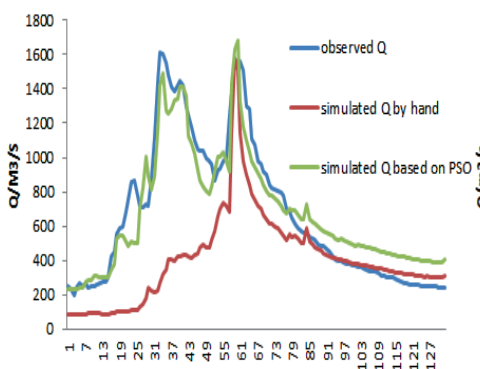

t/h

a.flood 1965080608

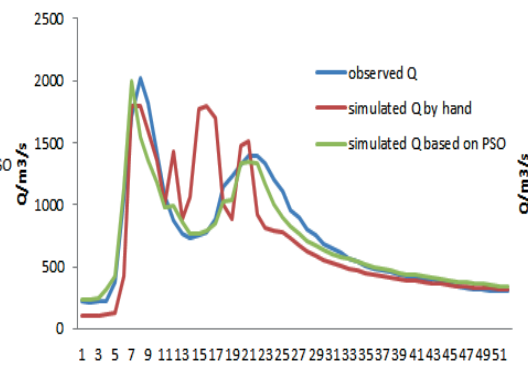

$\mathrm{t} / \mathrm{h}$

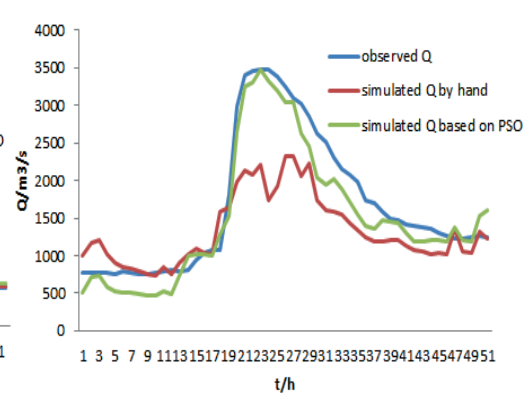

c. flood1970071214

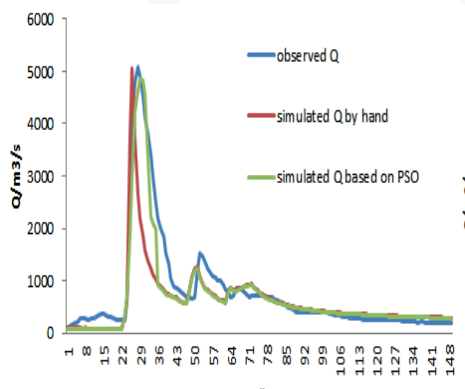

$\mathrm{t} / \mathrm{h}$

b.flood1966062020

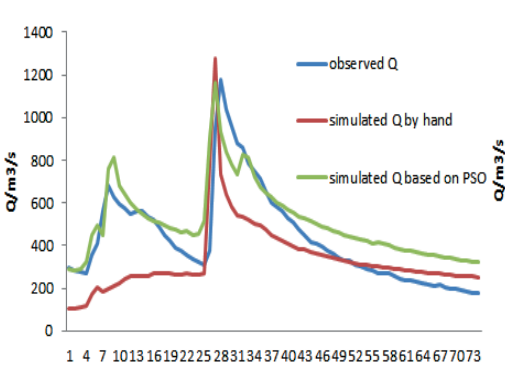

$\mathrm{t} / \mathrm{h}$

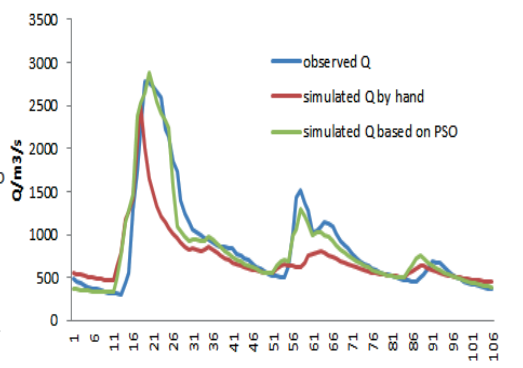

$\mathrm{t} / \mathrm{h}$

d.flood1977060804

Fig. 4 Simulated flood events with optimized parameters.

Acknowledgements This study is supported by the Special Research Grant for the Water Resources Industry (funding no. 201301070), the National Science \& Technology Pillar Program during the Twentieth Five-year Plan Period (funding no. 2012BAK10B06), and the Science and Technology Program of Guangdong Province (funding no. 2013B020200007).

\section{REFERENCES}

Abbott, M.B. et al. (1986a) An introduction to the European Hydrologic System-System Hydrologue Europeen, 'SHE', a: History and philosophy of a physically-based, distributed modelling system. Journal of Hydrology 87, 45-59.

Abbott, M.B. et al. (1986b) An Introduction to the European Hydrologic System-System Hydrologue Europeen, 'SHE', b: Structure of a physically based, distributed modeling system. Journal of Hydrology 87, 61-77.

Burnash, R.J.C. (1995) The NWS river forecast system-catchment modelling. In: Singh, V. P. (ed.) Computer Models of Watershed Hydrology, Water Resources Publications, Colorado, pp.311-366

Crawford, N.H. and Linsley, R.K. (1966) Digital simulation in hydrology, Stanford Watershed Model IV. Stanford Univ. Dep. Civ. Eng, Tech. Rep. 39.

Julien, P.Y, Saghafian, B. and Ogden, F.L. (1995) Raster-based hydrologic modeling of spatially-varied surface runoff. Water Resources Bulletin 31(3), 523-536.

Kouwen, N. (1988) WATFLOOD: A Micro-Computer based Flood Forecasting System based on Real-Time Weather Radar. Canadian Water Resources Journal 13(1), 62-77.

Liang, X., et al. (1994) A simple hydrologically based model of land surface water and energy fluxes for general circulation models. J. Geophys. Res. 99(D7), 14415-14428.

Sugawara, M. (1995) Tank model. In: Singh, V. P. (ed.), Computer Models of Watershed Hydrology, Water Resources Publications, Colorado, pp.165-214.

Todini, E. (1996) The ARNO rainfall-runoff model. Journal of Hydrology 175, 339-382.

Vieux, B.E. and Vieux, J.E. (2002) Vflo ${ }^{\mathrm{TM}}$ : A Real-Time Distributed Hydrologic Model. Proceedings of Second Federal Interagency Hydrologic Modeling Conference: Hydrologic Modeling for the 21st Century, July 28-August 1, 2002, Las Vegas, NV(downloaded from http://www.vieuxinc.com).

Wang, Z., Batelaan, O. and De Smedt, F. (1996) A distributed model for Water and Energy Transfer between Soil, Plants and Atmosphere (WetSpa). Phys. Chem. Earth 21, 189-193.

Yangbo Chen (2008) Liuxihe Model. Science and Technology Publishing Company: Bingjiang, 198pp.

Yangbo Chen, et al. (2011) Liuxihe Model and its modeling to river basin flood. Journal of Hydrologic Engineering 16(1), 33-50.

Zhao, R.J. (1977) Flood Forecasting Method for Humid Regions of China. East China College of Hydraulic Engineering, Nanjing, China. 